\title{
REMINISCENCES ABOUT STEVE FIENBERG
}

\author{
ADAM SMITH
}

Boston, Massachusetts

Steve was an outstanding scientist, an intellectual leader, and a mentor in the many communities of which he was a part. He possessed a charisma rare even among scientists of his stature. He was larger than life, in the best possible sense of the expression.

I first met Steve at a workshop in Bertinoro in 2005, the same place I met others whom I would encounter again and collaborate with over the years: John Abowd, Sesa Slavkovic, and Jerry Reiter. At the time, I was struck by Steve's command of a large swath of applied and theoretical statistics. Even more so, I was struck by his ability to capture people's attention, and his knack for conveying ideas (objections, often!) in just a few words, with perfect clarity.

I recall that I was also infuriated by his focus on techniques that were immediately applicable, and attacks that could be mounted in the current environment. And while I never fully saw eye to eye with him on this focus, I grew to appreciate that his concerns came from his desire to see both fundamental advances in science and methodology that would affect change in the near term. His questioning drove much of my later research activity, loathe though I was to admit it!

I also appreciated Steve's role in the many research communities that called him a member. Steve was a leader - tireless in organizing meetings and events, writing prolifically, and making sure that science's voice was heard by policymakers. He was also a mentor to many - generous with advice as well as with support. Even in the last months of his life, when he knew that his time was limited, he remained actively involved in many types of service and was busy writing letters of recommendation that would be useful to his mentees even after he had passed away.

Rest in peace, Steve. You were one of a kind, and you are missed.

Adam Smith

Key words and phrases: reminiscences, Fienberg.

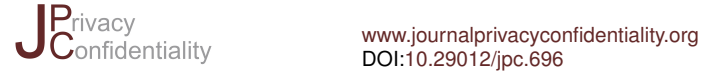

This work is licensed under the Creative Commons License Attribution-NonCommercial-NoDerivatives 4.0 International (CC BY-NC-ND 4.0). To view a copy of this license, visit https : //creativecommons .

org/licenses/by-nc-nd/4.0/ or send a letter to Creative Commons, 171 Second St, Suite

300, San Francisco, CA 94105, USA, or Eisenacher Strasse 2, 10777 Berlin, Germany 